\title{
Giardia intestinalis, a eukaryote without hydrogenosomes, produces hydrogen
}

\author{
David Lloyd, James R. Ralphs and Janine C. Harris
}

Microbiology (BIOSI 1, Main Building), Cardiff University, PO Box 915, Cardiff CF10 3TL, Wales, UK
Author for correspondence: David Lloyd. Tel: +44292087 4772. Fax: +442920874305. e-mail: LloydD@cardiff.ac.uk

The microaerophilic flagellated protist Giardia intestinalis, the commonest protozoal agent of intestinal infections worldwide, is of uncertain phylogeny, but is usually regarded as the earliest branching of the eukaryotic clades. Under strictly anaerobic conditions, a mass spectrometric investigation of gas production indicated a low level of generation of dihydrogen $\left(2 \mathrm{nmol} \mathrm{min} \mathbf{~ m e r}^{-1}\right.$ per $10^{7}$ organisms), about 10-fold lower than that in Trichomonas vaginalis under similar conditions. Hydrogen evolution was $\mathrm{O}_{2}$ sensitive, and inhibited by $100 \mu \mathrm{M}$ metronidazole. Fluorescent labelling of $G$. intestinalis cells using monoclonal antibodies to typical hydrogenosomal enzymes from $T$. vaginalis (malate enzyme, and succinyl-CoA synthetase $\alpha$ and $\beta$ subunits), and to the large-granule fraction (hydrogenosome-enriched, also from $T$. vaginalis) gave no discrete localization of epitopes. Cell-free extracts prepared under anaerobic conditions showed the presence of a CO-sensitive hydrogenase activity. This first report of hydrogen production in a eukaryote with no recognizable hydrogenosomes raises further questions about the early branching status of $G$. intestinalis; the physiological characterization of its hydrogenase, and its recently elucidated gene sequence, will aid further phylogenetic investigations.

Keywords: early branching eukaryotes, diplomonads, membrane inlet mass spectrometry, hydrogenase

\section{INTRODUCTION}

The ability of eukaryotes to produce dihydrogen is somewhat limited, despite the widespread occurrence of genes encoding hydrogenase (Horner et al. 2000). Dihydrogen is produced by some green algae in the light under anaerobic conditions, e.g. in Chlamydomonas reinhardtii (Happe et al., 1994), and in Scenedesmus obliquus (Schnackenberg et al., 1993). Other lower eukaryotes that generate hydrogen gas include the microaerophilic protozoa (Yarlett et al., 1982) and chytrid fungi, e.g. Neocallimastix patriciarum (Yarlett et al., 1986, 1987; Rees et al., 1998) isolated from the rumen. Like the microaerophilic pathogen Trichomonas vaginalis (Paget \& Lloyd 1990), and the cattle parasite Tritrichomonas foetus (Lloyd et al., 1983), these protists all possess hydrogenosomes, organelles specialized to produce dihydrogen from pyruvate (Lindmark \& Müller, 1973). Similar organelles have been shown in the free-living ciliates Plagiopyla frontata and Metopus contortus (Fenchel \& Finlay, 1992; Biagini et al., 1997a).

Hydrogenosomes have inner and outer membranes
(Finlay \& Fenchel, 1989), generate a transmembrane electrochemical potential (Humphreys et al., 1994, 1998) and have intra-organellar $\mathrm{Ca}^{2+}$-containing granules (Benchimol et al., 1982; Chapman et al., 1985; Biagini et al., 1997b); these are all characteristics shared by mitochondria (Lloyd, 1974). It is now generally believed that hydrogenosomal convergence in disparate descendent phyla (Lloyd et al., 1983) represents the emergence of secondarily derived mitochondria (Biagini et al., 1997c). Evolutionary selection pressures that favoured the necessary modifications (loss of respiratory chains that use cytochromes, and the proton-translocating systems that generate ATP by oxidative phosphorylation) were life under anoxic conditions (Fenchel \& Finlay, 1995) or under conditions of low $\mathrm{O}_{2}$ in microaerobic refuges (e.g. in sediments or in parasitic or symbiotic niches; Lloyd \& Williams, 1993).

One of the lower eukaryotic groups adapted to these conditions, the diplomonads, includes Giardia intestinalis, an important human pathogen that causes an estimated $2 \cdot 8 \times 10^{8}$ infections each year. Although this organism can be life-threatening in the immunocompro- 
mised, the very young or the very old (Adam, 1991), it is of uncertain phylogeny. It has been commonly assumed that this 'anaerobic amitochondriate' protist is 'ancient and primitive' on account of its many bacterial characteristics (pyrophosphate-biased energy metabolism, arginine dihydrolase pathway of energy production, etc.; Brown et al., 1998), and on the basis of RNA trees, that it represents an extant survivor typical of the earliest branch of the eukaryotes (Sogin, 1991; Leipe et al., 1993; Madigan et al., 2000). However, this assumption has recently been questioned (Embley \& Hirt, 1998), as genes for several typically mitochondrial proteins have been shown to be present in G. intestinalis (Soltys \& Gupta, 1994; Horner et al., 1996; Roger et al., 1998) and in T. vaginalis. Although open to various interpretations, this startling discovery might place the diplomonad as a recent derivative of an aerobic lineage. Furthermore, electron-transport activities (Ellis et al., 1993), and transmembrane electrochemical potential generation are associated with distinctive sites in this organism (Lloyd et al., 2002). These observations may be interpreted as suggesting that G. intestinalis is not an early branching eukaryote, but having been derived from an antecedent with mitochondria, should be allocated to a crown taxon (Lake, 1994). Here we show, despite earlier claims to the contrary, that G. intestinalis possesses hydrogenase and produces dihydrogen, even if it does not possess identifiable hydrogenosomes.

\section{METHODS}

Organisms and cultures. Giardia intestinalis Portland-1 strain ATCC 30888, was a gift of Michael R. Edwards, University of New South Wales, Sydney, Australia. Cultures were maintained in liquid $\mathrm{N}_{2}$ after cryopreservation in the presence of $10 \%$ (v/v) dimethyl sulphoxide. Trophozoites were cultured axenically and anaerobically in screw-capped Nunclon tubes (Life Technologies) at $37^{\circ} \mathrm{C}$ on Diamond's modified TY1-S33 medium containing $2 \%(\mathrm{w} / \mathrm{v})$ tryptone, $1 \%(\mathrm{w} / \mathrm{v})$ yeast extract, $0.5 \%(\mathrm{w} / \mathrm{v})$ glucose, $0.106 \%(\mathrm{w} / \mathrm{v})$ arginine, $0.2 \%$ $(\mathrm{w} / \mathrm{v}) \mathrm{NaCl}, 0 \cdot 1 \%(\mathrm{w} / \mathrm{v})$ cysteine, $0.1 \%(\mathrm{w} / \mathrm{v})$ bovine bile, $0.02 \%(\mathrm{w} / \mathrm{v})$ ascorbic acid, $0.0023 \%(\mathrm{w} / \mathrm{v})$ ammonium ferric citrate, $3 \%(\mathrm{v} / \mathrm{v})$ minimal essential medium with Earle's salt (Keister, 1983; Edwards et al., 1989), supplemented with $10 \%$ $(\mathrm{v} / \mathrm{v})$ heat-inactivated fetal calf serum. Subculturing was performed routinely at $48 \mathrm{~h}$ intervals by replacing the spent medium with fresh, chilling on ice for $20 \mathrm{~min}$, and inverting gently to detach the monolayer. Cells were counted on a Fuchs Rosenthal haemocytometer slide, using $0.4 \%$ (v/v) Trypan blue as a viability indicator; typically this gave cell numbers of $2 \times 10^{6} \mathrm{ml}^{-1}$. Trichomonas vaginalis was grown exactly as described by Diamond (1957). All cultures were monitored routinely to confirm axenic growth.

Harvesting. After chilling for $20 \mathrm{~min}$ in an ice bucket, tubes were shaken gently to dislodge adherent organisms. Cell numbers were counted and then centrifugation was at $1000 \mathrm{~g}$ (3000 r.p.m.) for $4 \mathrm{~min}$ at room temperature in a bench centrifuge (MSE Minor). After washing once with phosphatebuffered saline ( $\mathrm{pH} 7 \cdot 4$, PBS) and recentrifugation, organisms were finally resuspended in PBS or $0.31 \mathrm{M}$ mannitol solution (both at $\mathrm{pH} 7 \cdot 4$ ) and kept at $4{ }^{\circ} \mathrm{C}$.

Mass spectrometry. Dissolved gases were measured using a Hal series quadrupole mass spectrometer (Hiden Analytical) fitted with an inlet probe covered by a gas-permeable polymer membrane $(1.56 \mathrm{~mm}$ outside diameter, $0.5 \mathrm{~mm}$ internal diameter, $1 \mathrm{~cm}$ length) sealed into a $1 \mathrm{~cm}$ length of quartz-glass tube. The inlet orifice was $100 \mu \mathrm{m}$ diameter, and the membrane used was either silicone rubber (permeable to low-molecularmass volatiles as well as gases) or Mylar (polyethylene terephthalate), a polymer permeable to $\mathrm{H}_{2}$ and $\mathrm{CO}_{2}$, but only much less so to other gases and not penetrated by ethanol. Further details of the mass spectrometer are described elsewhere (Lloyd \& Scott, 1982; Lloyd et al., 1992). The probe was used to measure gases dissolved in a $5 \mathrm{ml}$ working volume held in a perspex vessel with magnetic stirring at 200 r.p.m. and $37^{\circ} \mathrm{C}$; the system was open for gas flow over the stable liquid vortex. A gas mixer (Lundsgaard \& Degn, 1973) was used to give step changes from argon to $5 \%$ oxygen in nitrogen in the gas phase above the stirred vortex. Mass-tocharge ratios used to measure the concentrations of $\mathrm{H}_{2}$, ethanol, $\mathrm{O}_{2}$ and $\mathrm{CO}_{2}$ were 2, 31, 32 and 44 respectively. Solubilities of $\mathrm{H}_{2}$ and $\mathrm{O}_{2}$ at $37^{\circ} \mathrm{C}$ were 750 and $1328 \mu \mathrm{M}$ respectively (Wilhelm et al., 1977). $\mathrm{CO}_{2}$ and ethanol calibrations employed additions of $10 \mathrm{mM} \mathrm{NaHCO}{ }_{3}$ or $\mathrm{C}_{2} \mathrm{H}_{5} \mathrm{OH}$.

Preparation of cell-free extracts. Packed organisms were resuspended in 5 vols $0.31 \mathrm{M}$ mannitol, then mixed with an equal volume of $0.1 \mathrm{~mm}$ diameter acid- and distilled-waterwashed glass beads in screw-cap sealed $2 \mathrm{ml}$ Nunclon tubes under argon. They were shaken at $4000 \mathrm{~Hz}$ for $20 \mathrm{~s}$ in a Braun MSK cell disintegrator. Beads and unbroken cells were removed by centrifugation at $1000 \mathrm{~g}$ for $2 \mathrm{~min}$. Assays were performed using the supernatant.

Immunolocalization. Following the method of Brugerolle et al. (2000), washed cell suspensions were fixed in PBS, pH 7·4, containing $3.5 \%$ formaldehyde for $20 \mathrm{~min}$ at room temperature. The cells were then permeabilized in PBS containing $0.5 \%$ Triton X-100 for $10 \mathrm{~min}$. After treatment with $0 \cdot 1 \mathrm{M}$ glycine in PBS for $15 \mathrm{~min}$, the cells were resuspended in $200 \mu \mathrm{l}$ of the primary antibody (undiluted mAb supernatant) and incubated for $2 \mathrm{~h}$ at room temperature. The antibodies used (kindly provided by Dr Guy Bruggerole, Clermont-Ferrand) were anti-malic enzyme (15 D7), anti- $\alpha$-subunit-succinyl-CoA synthetase (1C8), anti- $\beta$-subunit-succinyl-CoA synthetase (5H6) and anti-granule (XIV D2). After this period the cells were washed three times in PBS $(3 \times 30 \mathrm{~min})$ and then incubated for $1 \mathrm{~h}$ with anti-mouse $\operatorname{Ig}, \operatorname{IgG} / \mathrm{M}$ antibody conjugated with fluorescein isothiocyanate. After final washes in PBS $(3 \times 30 \mathrm{~min})$, the cells were mounted in $1: 1(\mathrm{v} / \mathrm{v})$ glycerol/PBS containing $10 \mathrm{mg}$ 1,4-diazabicyclo-(2,2,2)octane (DABCO) $\mathrm{ml}^{-1}$. Cells were viewed using a Molecular Dynamics Sarastro 2000 confocal laser scanning microscope. Control specimens were treated with the secondary antibody only.

Confocal laser scanning microscopy. Cells prepared for immunofluorescence were incubated with $0 \cdot 31 \mathrm{M}$ mannitol instead of PBS and viewed using a Molecular Dynamics Sarastro 2000 confocal laser scanning microscope. Specimens were scanned using a $25 \mathrm{~mW}$ argon laser with appropriate excitation and emission filters for fluorescein $(488 / 510 \mathrm{~nm})$. Specimens were examined using oil-immersion objectives, $\times 60(50 \mu \mathrm{m}$ confocal aperture $)$ and $\times 100(100 \mu \mathrm{m}$ confocal aperture). Series sections through samples were taken at $1 \mu \mathrm{m}$ intervals $(512 \times 512$ pixels; $\sim 0.5 \mu \mathrm{m}$ thick $)$, and three-dimensional constructs were prepared using Molecular Dynamics Volume Workbench running in Silicon Graphics UNIX workstation.

Materials. Gases were from Air Products; traces of $\mathrm{O}_{2}$ were removed from research-grade $\mathrm{N}_{2}$ using an 'Oxytrap' column 
(Alltech Associates). Tryptone was purchased from BectonDickinson, and trypticase from BioMérieux. Fetal calf serum was supplied by GibcoBRL, and Nunclon screw-capped culture tubes and cryopreservation vials were supplied through Life Technologies. All other chemicals were supplied by Sigma-Aldrich-Fluka.

\section{RESULTS}

Fig. 1 shows the responses of a washed intact cell suspension of $G$. intestinalis to successive cycles of anoxia and aerobiosis after addition of $20 \mathrm{mM}$ glucose, as monitored by membrane inlet mass spectrometry using a silicone rubber interface. After equilibration to the anaerobic state, dissolved $\mathrm{CO}_{2}$ and ethanol (a major fementation product under anoxic conditions), attained steady states. Switching the mobile gas phase to trace $\mathrm{O}_{2}$ (using a gas mixture containing $0.4 \mathrm{kPa} \mathrm{O}_{2}$ in $\mathrm{N}_{2}$ ) gave accelerated fermentation, even though the level of dissolved $\mathrm{O}_{2}$ was less than the detection limit of the mass spectrometer $\left(0 \cdot 1 \mu \mathrm{M} \mathrm{O}_{2}\right)$; this was indicated by elevated ethanol production and an increased $\mathrm{CO}_{2}$ concentration. The response time of the system is longer for ethanol than for fixed gases. Monitoring at $m / z=2\left(\right.$ for $\mathrm{H}_{2}^{+}$) indicated an increase, but calibrations in parallel with those at $m / z=31$ confirmed that this signal is derived by the fragmentation of ethanol in the vacuum system (Fig. 2a). The fact that the $m / z=2$ trend analysis exactly follows that at $m / z=31$ confirms that it does not arise from dihydrogen; in this experimental configuration (open to gas flow) the latter behaves as do all 'fixed gases', i.e. they reach steady states and do not accumulate as does a low-molecular-mass volatile (e.g. ethanol).

In order to avoid the interference of ethanol at $m / z=2$ while measuring $\mathrm{H}_{2}$, a chemical trap for ethanol (alcohol

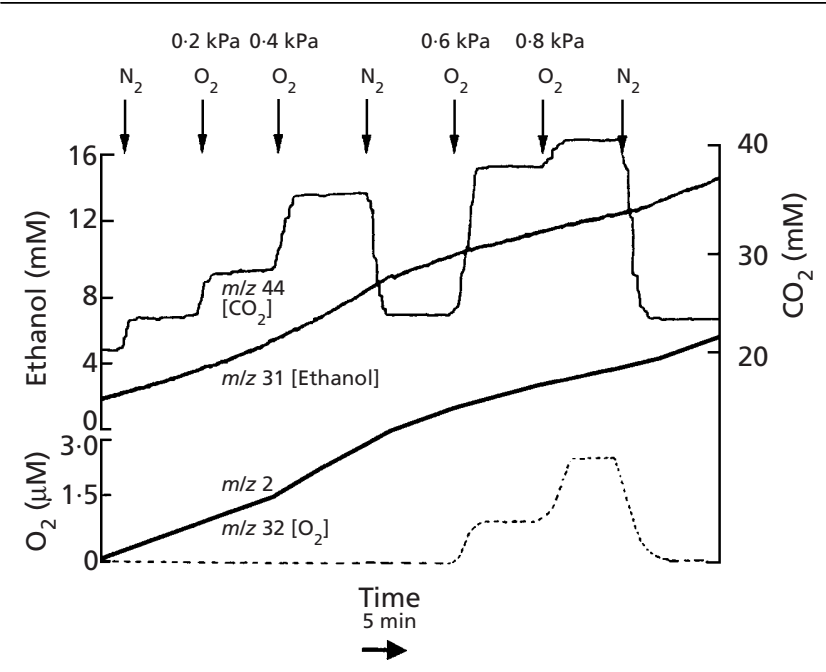

Fig. 1. Gas exchange measured in an open reaction vessel in a suspension of $G$. intestinalis. Washed organisms $\left(6 \times 10^{7}\right.$ organisms $\mathrm{ml}^{-1}$ ) were incubated in PBS with $20 \mathrm{mM}$ glucose. The temperature was $37^{\circ} \mathrm{C}$ and the membrane interface was silicone rubber. dehydrogenase plus semicarbazide) was included in the cell suspension, but this did not obviate the problem, as the mass spectrometer was able to compete with the enzyme for ethanol and still gave signals at both mass numbers.

A solution to this problem involved using a more selective gas-permeable membrane. Of several polymers (polyethylene, polypropylene, Teflon and polyethylene terephthalate), the last (Mylar) proved most successful with respect to restricted ethanol permeability. Fig. 2(b) shows that even at very high concentrations, ethanol gives no responses, but $\mathrm{H}_{2}$ can penetrate rapidly to give a mass spectrometric response with a short half-time. Fig. 3 shows an experiment on glucose utilization by whole cells of $G$. intestinalis in PBS using this Mylar inlet system to monitor gases continuously in a closed vessel. Initially, the organisms consumed dissolved $\mathrm{O}_{2}$, and this became undetectable by $8 \mathrm{~min}$. Only after this, when almost complete anoxia was attained, did the signal at $m / z=2$ increase as $\mathrm{H}_{2}$ was produced and accumulated continuously. Injection of air-saturated PBS (final $\left[\mathrm{O}_{2}\right]=8 \mu \mathrm{M}$ ) gave an almost immediate cessation of $\mathrm{H}_{2}$ generation. Resumption of $\mathrm{H}_{2}$ evolution only occurred when added $\mathrm{O}_{2}$ had been depleted again. Finally, addition of $100 \mu \mathrm{M}$ metronidazole gave complete arrest of hydrogenogenesis.

\section{Experiments with cell-free extracts}

Fig. 4 shows the absorbance changes at $600 \mathrm{~nm}$ during incubation of cell-free extract with methyl viologen in closed cuvettes under an atmosphere of either $\mathrm{N}_{2}$ or $\mathrm{H}_{2}$ in a buffer containing $40 \mathrm{mM}$ dithiothreitol. No dye reduction occurred in the presence of heat-inactivated cell-free extract. The presence of hydrogenase in the active extract was indicated by dye reduction under $\mathrm{H}_{2}$ at a rate proportional to the volume of extract added. No reaction occurred under a gas phase of $\mathrm{N}_{2}$ or when air was admitted to the reaction mixture during the hydrogenase reaction. $\mathrm{CO}(3 \mu \mathrm{M})$ inhibited the reaction by $20 \%$ when $\mathrm{H}_{2}$ was present at $820 \mu \mathrm{M} ; 16 \mu \mathrm{M} \mathrm{CO}$ gave $70 \%$ inhibition.

\section{Immunocytology}

Incubation of fixed $G$. intestinalis with fluorescentlabelled monoclonal antibodies to hydrogenosomes isolated from T. vaginalis or to typical hydrogenosomal enzymes (also purified from T.vaginalis) as described by Bruggerole et al. (2000) gave no discrete localization as revealed by examination using confocal laser scanning microscopy. The fluorescent hydrogenosome labels (fluorescein $\lambda_{\text {excit }}=488 \mathrm{~nm}, \lambda_{\text {emiss }}=510 \mathrm{~nm}$ ) gave positive results for the characteristic distribution of these organelles and for the hydrogenosomal location of malate enzyme and succinyl-CoA synthetase in $T$. vaginalis, but in $G$. intestinalis only faint yellow-green fluorescence was observed throughout the organisms (not shown). Thus no discrete localization of typical hydrogenosomal epitopes was found in the diplomonad. 

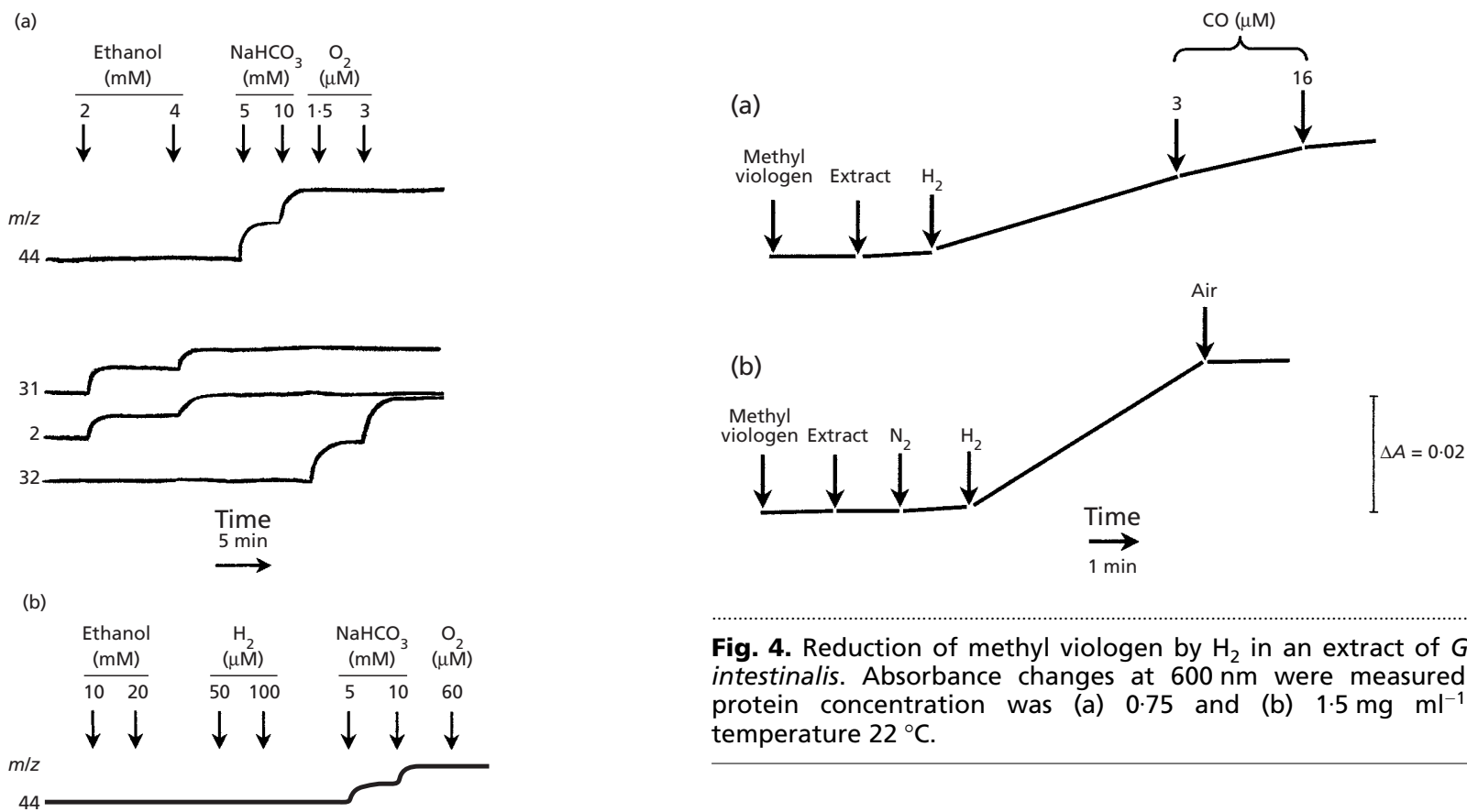

Fig. 4. Reduction of methyl viologen by $\mathrm{H}_{2}$ in an extract of $G$. intestinalis. Absorbance changes at $600 \mathrm{~nm}$ were measured; protein concentration was (a) 0.75 and (b) $1.5 \mathrm{mg} \mathrm{ml}^{-1}$; temperature $22^{\circ} \mathrm{C}$.

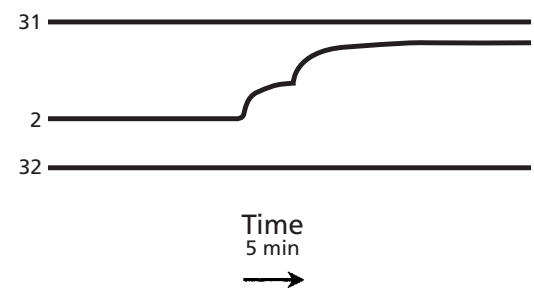

\section{DISCUSSION}

The lack of mitochondria and peroxisomes, and the possession of only a rudimentary Golgi body in the trophozoite may not necessarily point to a 'primitive' status for G. intestinalis, but rather to the secondary loss of completely functional organelles during evolution as a parasite (Lloyd et al., 1983; Embley \& Hirt, 1998).

Our observation that this organism produces dihydrogen, despite its apparent lack of a discrete structural entity that can be recognized as a hydrogenosome, even by the criterion of immunological cross-reaction with proteins isolated from the hydrogenosomes of another Mylar. (a) Calibrations for $\mathrm{O}_{2}, \mathrm{CO}_{2}$ and ethanol and $\mathrm{H}_{2}$ at $\mathrm{m} / \mathrm{z}$ 32,44 and 31 and 2 , respectively, using silicone rubber. (b) Calibrations for $\mathrm{CO}_{2}$, ethanol and $\mathrm{H}_{2}$ at $\mathrm{m} / \mathrm{z} 44,31$ and 2, respectively, using a Mylar membrane.

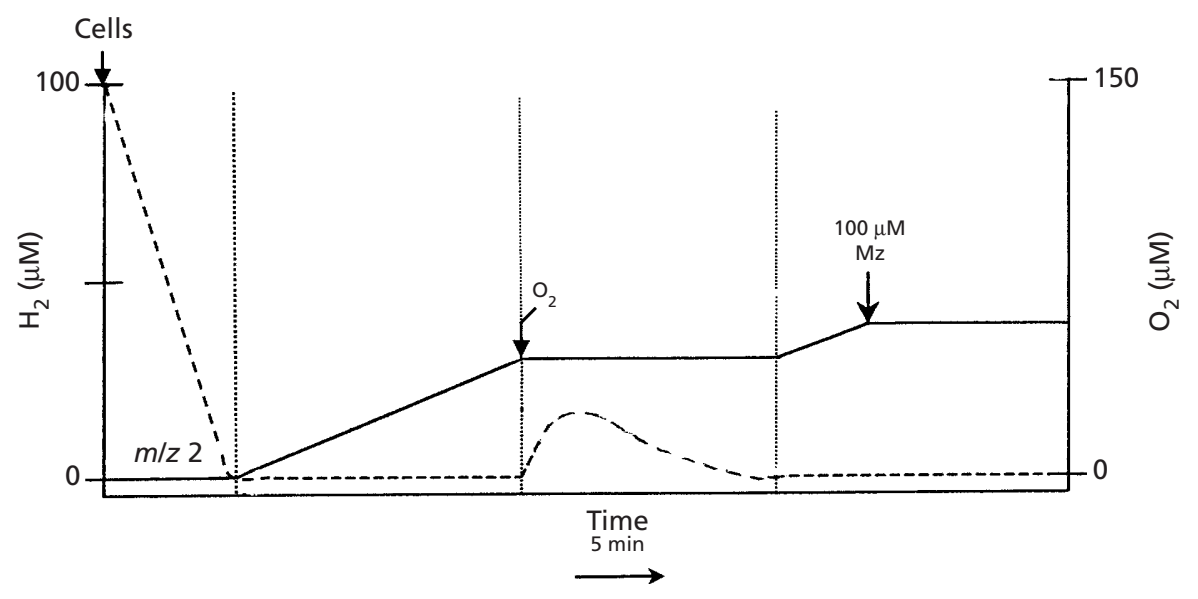

Fig. 3. Gas exchange measured in a suspension of $G$. intestinalis. Washed organisms $\left(6 \times 10^{7}\right.$ organisms $\left.\mathrm{ml}^{-1}\right)$ were $^{\circ}$ incubated in PBS with $20 \mathrm{mM}$ glucose in a closed reaction vessel. The temperature was $37^{\circ} \mathrm{C}$ and the membrane interface was Mylar. See text for details. Mz, metronidazole. 
microaerophilic lower eukaryote, T. vaginalis (Bruggerole et al., 2000), provides a further reason for a new emphasis on its uncertain taxonomic position. Dihydrogen production rates $\left(2 \mathrm{nmol} \mathrm{m^{-1 }}\right.$ per $10^{7}$ organisms) were about 10 -fold lower than in T. vaginalis (Ellis et al., 1992).

The hydrogenase responsible for the dihydrogenase generation in G. intestinalis shows characteristics typical of an (iron-only) [Fe] hydrogenase. Thus its activity, as measured by $\mathrm{H}_{2}$-dependent reduction of methyl viologen, is extremely $\mathrm{O}_{2}$ sensitive and is also inhibited by low concentrations of $\mathrm{CO}$. Other classes of hydrogenase include those containing $\mathrm{Ni}$, or $\mathrm{Ni}$ and $\mathrm{Se}$ as well as acidlabile sulphur; these hydrogenases are relatively $\mathrm{CO}$ insensitive (Cammack et al., 1985).

Other microaerophilic protists containing hydrogenosome-localized hydrogenase include the parasitic species, the trichomonads (Lindmark \& Müller, 1973), six different species of the symbiotic rumen protists examined (see Yarlett et al., 1981, 1983a, b, 1984; Hillman et al., 1985; Elllis et al., 1991a, b, c), chytrid fungi (Yarlett et al., 1986, 1987; Rees et al., 1998) and the highly anaerobic free-living sediment-dwelling ciliate Metopus contortus (Biagini, 1997a). Clearly, these organisms are widely separated phylogenetically (Lloyd et al., 1983). Molecular analysis, as well as likelihood ratio tests and parametric bootstrapping, suggest that the $[\mathrm{Fe}]$ hydrogenases in microaerophilic lower eukaryotes are not monophyletic, even though those from organisms not bearing hydrogenosomes, Entamoeba histolytica and Spironucleus barkhanus, together with a newly described third hydrogenase from T. vaginalis, might possibly be (Horner et al., 2000).

The complete sequence of the G. intestinalis hydrogenase gene (http://www.ncbi.nlm.nih.gov:80/, GenBank accession no. AF242293), available only after the experiments described here were completed (J. E. Nixon, J. Field, J. Samuelson \& M. L. Sogin, unpublished), places Giardia close to E. histolytica and S. barkhanus. The Spironucleus sequence is also complete (Horner et al., 2000), and neither that gene nor the one for Giardia hydrogenase shows any obvious N-terminus motif that would target it to an organelle. This observation correlates with our unsuccessful attempts to locate hydrogenosomes in $G$. intestinalis reported here.

Monoclonal antibodies for hydrogenosomal malic enzyme, $\alpha$ and $\beta$-subunits of succinyl-CoA synthetase, and granules were incubated with $T$. vaginalis (positive control) and $G$. intestinalis to see if this organism contained any of the hydrogenosomal enzymes. All of the $T$. vaginalis tests showed discrete localizations within the cells and no fluorescence when the cells were incubated with fluorescently labelled secondary antibody only (negative control). All of the localizations in the trichomonad were discrete, and in organelles of the same dimensions and distributions. However, incubation of Giardia with the same antibodies did not result in any discrete localization within the cells. This suggests that Giardia does not contain any of the hydrogenosomal proteins screened for by this assay; however, this does not necessarily indicate that these are not present. Monoclonal antibodies are highly specific, and even a change of one amino acid of an enzyme can result in a different epitope; then no binding of the antibody would occur.

Extensive mechanistic research on hydrogenases indicates that evolutionary relationships can be elucidated. This first report of an hydrogenase in G. intestinalis and the progress of the Giardia genome project (Adam, 2000) paves the way for molecular analyses (Horner et al., 2000) that may help phylogenetic studies on $G$. intestinalis as has been the case for E. histolytica (Rosenthal et al., 1997). These studies may also have important implications for hypotheses regarding the origin of eukaryotes (Gupta \& Golding, 1996; LópezGarcia \& Moreira, 1999).

Further work is in progress to determine the specific location of the hydrogenase in G. intestinalis, especially with regard to its membrane association. Possible functions include intracellular redox balancing by this 'output hydrogenase'. Previous metabolic analysis of fermentation pathways reveals tight control of apportionment of electron flux between pathways divergent from the pyruvate pool to alanine, or ethanol or acetate $+\mathrm{CO}_{2}$ (Paget et al., 1990, 1993) most likely via the redox balance of the $\mathrm{NADH} / \mathrm{NAD}^{+}$couple (Paget et al., 1993). Intracellular $\mathrm{O}_{2}$ concentration is presumably sensed in order to provide the homeodynamic modulation at this important branch point (Lloyd et al. 2002). The $\mathrm{O}_{2}$ sensitivity of hydrogenase reported here strongly suggests that dihydrogen serves as an alternative product, the generation of which can serve as a process for the dissipation of excess reducing power, only necessary under highly anaerobic conditions. Clearly, control of intracellular redox state is paramount in an environment that has fluctuating redox and $\mathrm{O}_{2}$ levels. Other possible functions may also come to light if the hydrogenase turns out to be a reversible transmembrane enzyme with a dual hydrogen-uptake/output role, also capable of the generation of a proton-translocating transmembrane electrochemical potential.

\section{ACKNOWLEDGEMENTS}

We gratefully acknowledge gifts of antibodies from Dr Guy Bruggerole, Clermont-Ferrand. J.C.H. was financially supported by Cultech Limited, Swansea.

\section{REFERENCES}

Adam, R. D. (1991). The biology of Giardia spp. Microbiol Rev 55, 706-732.

Adam, R. D. (2000). The Giardia genome project. Int J Parasitol 30, 475-484.

Benchimol, M., Elias, C. A. \& DeSouza, W. (1982). Tritrichomonas foetus: ultrastructural localisation of calcium in the plasmamembrane and in the hydrogenosome. Exp Parasitol 54, 277-284. 
Biagini, G. A., Hayes, A. J., Suller, M. T. E., Winters, C., Finlay, B. J. \& Lloyd, D. (1997a). Hydrogenosomes of Metopus contortus physiologically resemble mitochondria. Microbiology 143, 16231629.

Biagini, G. A., van der Giesen, M., Hill, B., Winters, C. \& Lloyd, D. (1997b). $\mathrm{Ca}^{2+}$ accumulation in the hydrogenosomes of Neocallimastix frontalis L2, a mitochondria-like physiological role. FEMS Microbiol Lett 149, 227-232.

Biagini, G. A., Finlay, B. \& Lloyd, D. (1997c). Evolution of the hydrogenosome. FEMS Microbiol Lett 153, 133-140.

Brown, D. M., Upcroft, J. A., Edwards, M. R. \& Upcroft, P. (1998). Anaerobic bacterial metabolism in the ancient eukaryote Giardia duodenalis. Int J Parasitol 28, 149-164.

Brugerolle, G., Bricheux, G. \& Coffe, G. (2000). Immunolocalization of two hydrogenosomal enzymes of Trichomonas vaginalis. Parasitol Res 86, 30-35.

Cammack, R., Hall, D. O. \& Rao, K. K. (1985). Hydrogenases structure and applications in hydrogen production. In Microbial Gas Metabolism, pp. 75-102. Edited by R. K. Poole \& C. S. Dow. London: Academic Press.

Chapman, A., Hann, A. O., Linstead, D. \& Lloyd, D. (1985) Dispersive X-ray microanalysis of membrane associated inclusions in hydrogenosomes isolated from Trichomonas vaginalis. $J$ Gen Microbiol 131, 2933-2939.

Diamond, L. S. (1957). The establishment of various trichomonads in animals and man in axenic culture. J Parasitol 43, 488-490.

Edwards, M. R., Gilroy, F. V., Jimenez, B. M. \& O'Sullivan, W. J. (1989). Alanine is a major end product of metabolism by Giardia lamblia: a proton nuclear magnetic resonance study. Mol Biochem Parasitol 37, 19-26.

Ellis, J. E., Mclntyre, P. S., Saleh, M., Williams, A. G. \& Lloyd, D. (1991a). Influence of $\mathrm{CO}_{2}$ and low concentrations of $\mathrm{O}_{2}$ on fermentative metabolism of the rumen ciliate Polyplastron multivesciculatum. Appl Environ Microbiol 57, 1400-1407.

Ellis, J. E., Mclntyre, P. S., Saleh, M., Williams, A. G. \& Lloyd, D. (1991b). Influence of $\mathrm{CO}_{2}$ and low concentrations of $\mathrm{O}_{2}$ on fermentative metabolism of the rumen ciliate Dasytricha ruminantium. J Gen Microbiol 147, 1409-1417.

Ellis, J. E., McIntyre, P. S., Saleh, M., Williams, A. G. \& Lloyd, D. (1991c). The influence of minimal concentrations of $\mathrm{O}_{2}$ on the fermentative metabolism of the rumen entodimiomorphid ciliate, Eudiplodinium maggii. Curr Microbiol 23, 245-251.

Ellis, J. E., Cole, D. \& Lloyd, D. (1992). Influence of oxygen on the fermentative metabolism of metronidazole-sensitive and resistant strains of Trichomonas vaginalis. Mol Biochem Parasitol 56, $79-88$.

Ellis, J. E., Williams, R., Cole, D., Cammack, R. \& Lloyd, D. (1993). Electron transport components of the parasitic protozoon, Giardia lamblia. FEBS Lett 325, 196-200.

Embley, T. M. \& Hirt, R. P. (1998). Early branching eukaryotes? Curr Opin Genet Dev 8, 624-629.

Fenchel, T. \& Finlay, B. J. (1992). Production of methane and hydrogen by anaerobic ciliates containing symbiotic methanogens. Arch Microbiol 157, 475-480.

Fenchel, T. \& Finlay, B. J. (1995). Ecology and Evolution in Anoxic Worlds. Oxford: Oxford University Press.

Finlay, B. J. \& Fenchel, T. (1989). Hydrogenosomes in some anaerobic protozoa resemble mitochondria. FEMS Microbiol Lett 65, 311-314.

Gupta, R. S. \& Golding, G. B. (1996). The origin of the eukaryotic cell. Trends Biochem Sci 21, 166-171.
Happe, T., Mosler, B. \& Naber, J. D. (1994). Induction, localization and metal content of hydrogenase in the green alga Chlamydomonas reinhardtii. Eur J Biochem 222, 769-774.

Hillman, K., Lloyd, D., Scott, R. I. \& Williams, A. G. (1985). The effect of $\mathrm{O}_{2}$ on $\mathrm{H}_{2}$ production by rumen holotrich protozoa as determined by membrane inlet mass spectrometry. In Gas Metabolism, pp. 271-277. Edited by R. K. Poole \& C. S. Dow. London: Academic Press.

Horner, D., Hirt, R. P., Kilvington, S., Lloyd, D. \& Embley, T. M. (1996). Molecular data suggest an earlier acquisition of the mitochondrial endosymbiont. Proc $R$ Soc B Biol Sci 263, 1053-1059.

Horner, D. S., Foster, P. G. \& Embley, T. M. (2000). Iron hydrogenases and the evolution of anaerobic eukaryotes. Mol Biol Evol $17,1695-1709$.

Humphreys, M., Ralphs, J., Durrant, L. \& Lloyd, D. (1994). Hydrogenosomes in trichomonads are $\mathrm{Ca}^{2+}$-stores and have a transmembrane electrochemical potential. Biochem Soc Trans 22, $324 \mathrm{~S}$.

Humphreys, M., Ralphs, J., Durrant, L. \& Lloyd, D. (1998). Confocal laser scanning microscopy of trichomonad hydrogenosomes store calcium and show a membrane potential. Eur J Protistol 34, 356-362.

Keister, D. B. (1983). Axenic culture of Giardia lamblia in TYI-S33 medium supplemented with bile. Trans R Soc Trop Med Hyg 77, 487-488.

Lake, J. A. (1994). Reconstructing evolutionary trees from DNA and protein sequences: paralinear distances. Proc Natl Acad Sci U S A 91, 1455-1459.

Leipe, D. D., Gunderson, J. H., Nerad, T. A. \& Sogin, M. L. (1993). Small subunit ribosomal RNA of Hexamita inflata and the quest for the first branch in the eukaryotic tree. Mol Biochem Parasitol 59, 41-48.

Lindmark, D. G. \& Müller, M. (1973). Hydrogenosome, a cytoplasmic organelle of the anaerobic flagellate Tritrichomonas foetus and its role in pyruvate metabolism. J Biol Chem 248, 7724-7728.

Lloyd, D. (1974). The Mitochondria of Microrganisms. London: Academic Press.

Lloyd, D. \& Scott, R. I. (1982). Direct measurement of dissolved gases using membrane inlet mass spectrometry. J Microbiol Methods 1, 313-320.

Lloyd, D. \& Williams, A. G. (1993). Biological activities of symbiotic and parasitic protists in low $\mathrm{O}_{2}$ environments. $A d v$ Microb Ecol 13, 211-262.

Lloyd, D., Williams, A. G., Yarlett, N. \& Hillman, K. (1983). Similarities between rumen ciliates and trichomonads: both possess hydrogenosomes. Abstr Int Soc Evol Protistol, 5th Meeting, Banyuls-sur-Mer, abstract 26.

Lloyd, D., Ellis, J. E., Hillman, K. \& Williams, A. G. (1992). Membrane inlet mass spectrometry: probing the rumen ecosystem. J Appl Bacteriol Symp Suppl 73, 1555-1635.

Lloyd, D., Harris, J. C., Biagini, G. A. \& 8 other authors (2002). Oxygen homeodynamics in Giardia. In Giardia, a Cosmopolitan Parasite, edited by P. Wallis. Wallingford: CAB International (in press).

López-Garcia, P. \& Moreira, D. (1999). Metabolic symbiosis at the origin of eukaryotes. Trends Biochem Sci 24, 88-93.

Lundsgaard, J. \& Degn, H. (1973). Digital regulation of gas flow rates and composition of gas mixtures. IEEE Trans Biomed Eng 20, 384-387. 
Madigan, M. T., Martinko, J. M. \& Parker, J. (2000). Biology of Microorganisms, 9th edn. Upper Saddle River, NJ: Prentice Hall.

Paget, T. A. \& Lloyd, D. (1990). Trichomonas vaginalis requires traces of oxygen and high concentrations of carbon dioxide for growth. Mol Biochem Parasitol 41, 65-72.

Paget, T. A., Rayner, M. H., Shipp, D. W. E. \& Lloyd, D. (1990). Giardia lamblia produces alanine anaerobically but not in the presence of $\mathrm{O}_{2}$. Mol Biochem Parasitol 42, 63-68.

Paget, T. A., Kelly, M. L., Jarroll, E. L., Lindmark, D. G. \& Lloyd, D. (1993). The effects of oxygen on fermentation in Giardia lamblia. Mol Biochem Parasitol 57, 65-72.

Rees, E. M. R., Lloyd, D. \& Williams, A. G. (1998). The effects of differing concentrations of $\mathrm{CO}_{2}$ and $\mathrm{O}_{2}$ on the fermentative metabolisms of the rumen fungi Neocallimastix patriciarum and Neocallimastix frontalis L2. Can J Microbiol 44, 819-824.

Roger, A. J., Clark, C. G. \& Doolittle, W. F. (1998). A possible mitochondrial gene in the early branching amitochondriate protist Trichomonas vaginalis. Proc Natl Acad Sci USA 95, 229-234.

Rosenthal, B., Zhiming, M., Caplivski, D., Ghosh, S., de la Vega, H., Graf, T. \& Samuelson, J. (1997). Evidence for the bacterial origin of genes encoding fermentation enzymes of the amitochondriate parasite Entamoeba histolytica. J Bacteriol 179, 3736-3745.

Schnackenberg, J., Schulz, R. \& Senger, H. (1993). Characterization and purification of a hydrogenase for the green alga Scenedesmus obliquus. FEBS Lett 327, 21-24.

Sogin, M. L. (1991). Early evolution and the origin of eukaryotes. Curr Opin Genet Dev 1, 457-463.

Soltys, B. J. \& Gupta, R. S. (1994). Presence and cellular distribu- tions of a $60 \mathrm{kDa}$ protein related to mitochondrial HSP-60 in Giardia lamblia. J Parasitol 80, 580-590.

Wilhelm, E., Battino, R. \& Wilcock, R. J. (1977). Low pressure solubilities of gases in liquid waters. Chem Rev 77, 219-362.

Yarlett, N., Hann, A. C., Lloyd, D. \& Williams, A. G. (1981). Hydrogenosomes in the rumen protozoon Dasytricha ruminantium. Biochem J 200, 365-372.

Yarlett, N., Lloyd, D. \& Williams, A. G. (1982). Respiration of the rumen ciliate Dastricha ruminantium Schuberg. Biochem J 206, 259-266.

Yarlett, N., Hann, A. C., Lloyd, D. \& Williams, A. G. (1983a). Hydrogenosomes in a mixed isolate of Isotricha prostoma and Isotricha intestinalis from ovine rumen contents. Comp Biochem Physiol 74B, 357-364.

Yarlett, N., Scott, R. I., Williams, A. G. \& Lloyd, D. (1983b). A note on the effects of oxygen on hydrogen production by the rumen protozoon Dastricha ruminantium Schuberg. J Appl Bacteriol 55, 359-361.

Yarlett, N., Coleman, G. S., Williams, A. G. \& Lloyd, D. (1984). Hydrogenosomes in known species of rumen entodiniomorphid protozoa. FEMS Microbiol Lett 21, 15-19.

Yarlett, N., Orpin, C. G., Munn, E. A., Yarlett, N. C. \& Greenwood, C. A. (1986). Hydrogenosomes in the rumen fungus Neocallimastix patriciarum. Biochem J 236, 729-739.

Yarlett, N., Rowlands, C., Yarlett, N. C., Evans, J. C. \& Lloyd, D. (1987). Respiration in the hydrogenosome-containing fungus Neocallimastix patriciarum. Arch Microbiol 148, 25-28.

Received 19 July 2001; revised 22 October 2001; accepted 16 November 2001. 